CHINA IN A POLYCENTRIC WORLD 
C ONTRIB U T OR S

HELEN H. CHEN

EUGENE CHEN EOYANG

MARK E. FRANCIS

ANN-MARIE HSIUNG

FENG-YING MING

GRETA AI-YU NIU

DAVID PALUMBO-LIU

MICHELLE YEH

ZHANG LONGXI

YINGJIN ZHANG

JOHN YU ZOU 


\title{
CHINA IN A POLYCENTRIC WORLD
}

Essays in Chinese Comparative Literature

\author{
Edited by Y I N G J I N Z H A N G
}

STANFORD UNIVERSITY PRESS

Stanford, California 
Stanford University Press

Stanford, California

(C) 1998 by the Board of Trustees of the Leland Stanford Junior University

Printed in the United States of America

CIP data appear at the end of the book 
For Su, Mimi, and Alex 


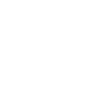

